\title{
The impact of COVID-19 on the well-being, education and clinical practice of general practice trainees and trainers: a national cross- sectional study
}

Lotta Coenen ${ }^{1 *}\left(\mathbb{0}\right.$, Louise Vanden Poel ${ }^{2}$, Birgitte Schoenmakers ${ }^{3}$ (D) Arne Van Renterghem ${ }^{4}$, Guy Gielis $^{5}$, Roy Remmen ${ }^{6}$ (D) and Nele R. Michels ${ }^{6}$ (D)

\begin{abstract}
Background: COVID-19 has changed General Practice (GP) education as well as GP clinical activities. These changes have had an impact on the well-being of medical trainees and the role of GP plays in the society. We have therefore aimed to investigate the impact that COVID-19 has had on GP trainees and trainers in four domains: education, workload, practice organization and the role of GP in society.

Design: a cross-sectional study design was used.

Methods: The Interuniversity Centre for the Education of General Practitioners sent an online survey with closeended and open-ended questions to all GP trainees and trainers in Flanders, active in the period March - September 2020. Descriptive statistics were performed to analyze the quantitative data and thematic analysis for the qualitative data.

Results: 216 (response 25\%) GP trainees and 311 (response 26\%) trainers participated. GP trainees $(63 \%, N=136)$ and trainers $(76 \%, N=236)$ reported new learning opportunities since the COVID-19 pandemic. The introduction of telehealth consulting and changing guidelines required new communication and organizational skills. Most of the GP trainees $(75 \%, n=162)$ and trainers $(71 \%, n=221)$ experienced more stress at work and an overload of administrative work. The unfamiliarity with a new infectious disease and the fact that COVID-19 care compromised general GP clinical activities, created insecurity among GP trainers and trainees. Moreover, GP trainees felt that general GP activities were insufficiently covered during the COVID-19 pandemic for their training in GP. GP trainers and trainees experienced mutual support, and secondary support came from other direct colleagues. Measures such as reducing the writing of medical certificates and financial support for administrative and (para) medical support can help to reprioritize the core of GP care.
\end{abstract}

COVID-19 has enhanced the use of digital learning over peer-to-peer learning and lectures. However, GP trainees and trainers preferred blended learning educational activities.

\footnotetext{
*Correspondence: lotta_coenen@live.be

1 Department of Family Medicine and chronic care, Vrije Universiteit

Brussels, Laarbeeklaan 103, 1090 Brussels, Belgium

Full list of author information is available at the end of the article
}

(C) The Author(s) 2022. Open Access This article is licensed under a Creative Commons Attribution 4.0 International License, which permits use, sharing, adaptation, distribution and reproduction in any medium or format, as long as you give appropriate credit to the original author(s) and the source, provide a link to the Creative Commons licence, and indicate if changes were made. The images or other third party material in this article are included in the article's Creative Commons licence, unless indicated otherwise in a credit line to the material. If material is not included in the article's Creative Commons licence and your intended use is not permitted by statutory regulation or exceeds the permitted use, you will need to obtain permission directly from the copyright holder. To view a copy of this licence, visit http://creativecommons.org/licenses/by/4.0/. The Creative Commons Public Domain Dedication waiver (http://creativeco mmons.org/publicdomain/zero/1.0/) applies to the data made available in this article, unless otherwise stated in a credit line to the data. 
Conclusions: COVID-19 has created learning opportunities such as telehealth consulting and a flexible organization structure. To ensure quality GP education during the pandemic and beyond, regular GP care should remain the core activity of GP trainees and trainers and a balance between all different learning methods should be found.

Keywords: COVID-19, General Practice, Medical education, Workplace learning, Mental health, Health care organization, Telehealth

\section{Background}

Since the first cases of COVID-19 presented itself in China in December 2019, the virus has spread rapidly around the globe [1] Due to the rapid growth of the pandemic in Belgium, the national government decided to enforce a lockdown regime starting from 18th of March 2020 [2]. Universities were closed, and education was converted to Online learning. Similar policies were applied in many countries [3-7]. In this ever-changing world, training doctors may also have become increasingly challenging.

In some countries, trainees' clinical activity was suspended, whereas in other countries they may have been actively engaged in COVID-19 care $[6,8,9]$. The level of active participation in COVID-19 varied over specialties [8-10]. Studies have suggested that trainees' education has vastly changed because of COVID-19 [5-11]. Firstly, lectures were converted to online learning $[6-8,12]$. Secondly, education opportunities were reduced, [13] given that COVID-19 care was prioritized [6-10]. Moreover, trainees had more responsibilities and a higher workload because of service reorganization $[5,7,8,10]$. Furthermore, medical professionals have been more prone to infection by COVID-19, which has required additional service organization [14]. Regarding training activities, this often meant a reduction in supervision and intervision sessions $[8,9,11]$. Additionally, research has suggested that working as a medical professional during the COVID-19 pandemic had a major impact on trainees' well-being, such as an increase in stress, anxiety and loneliness $[8-12,15,16]$.

Whereas the altered work-life balance of in-hospital trainees was reported, little attention has been paid to their educators' experiences. With COVID-19 causing a drastic change in practice organization and as such medical educators had to alter the structure of education activities [7-10]. Formal education activities were limited and instead were switched to more opportunistic educational discussions [8-11, 17]. Furthermore remote clinical supervision has been introduced $[7,8,10$, $11,17]$. In a short period of time peer-to-peer sessions and lectures had to be switched to online sessions. The literature describes study models to facilitate the switch in education organization, however educator's experience is seldom to be evaluated [17-20]. Furthermore, several studies have described the experiences of in-hospital trainees engaged in COVID-19 care and the consequences for their education $[7,9,11]$. However, only one study investigated the experiences of General Practice trainees (GP trainees) [10]. Therefore, we investigated the impact of COVID-19 on well-being, education and clinical practice of both GP trainees and General Practice trainers (GP trainers). We aimed to identify challenges, opportunities and support systems for GP trainees and GP trainers concerning four domains: education, workload, practice organization and the function of general practice (GP) in society.

\section{Study context}

The GP education in Flanders is provided through an interuniversity program by all four Dutch-speaking medical schools and is coordinated by the Interuniversity Centre for the Education of General Practitioners (ICHO).

Most of the time, GP trainees are active in clinical practice $(80 \%)$, where they work autonomously with daily supervision of a GP trainer. Besides clinical practice, trainees invest their time in organized study activities such as lectures, research activities and in improving their personal learning curve. Moreover, they participate in seminars composed of 10-12 trainees coached by a GP tutor. During these sessions, GP trainees can discuss and learn from their peers in a safe environment.

The COVID-19 pandemic has affected the organization of the GP trainees' program in several ways. Since 18th of March 2020, the Belgian government decided to put all non-urgent medical health care on hold. On 27th of April 2020, regular health care was reassumed [2, 21]. GP trainees were engaged in their GP trainers' practice as well as in COVID-19 specific centers. Besides the organization of COVID-19 care centers, the Belgian health authorities decided to remunerate telephonic and video consults and telehealth consulting was actively promoted and implemented in GPs work [22]. Since 18th of March 2020, all seminars, lectures and exams were converted to online sessions, except for seminars during the summer holidays.

When the Belgian government decided to put all nonurgent medical health care on hold, 5/100,000 inhabitants per day were diagnosed with COVID-19. By May 30th this number decreased to $0.2 / 100,000$. However, 
when the survey was launched in September 2020 the daily incidence of new cases increased up to $28 / 100,000$ $[23,24]$.

\section{Methodology}

Data was collected through an online survey. The survey encompassed five sections and aimed to obtain quantitative and qualitative data. Firstly, we surveyed the demographics of the participant and the characteristics of their practice. Secondly, the survey focused on four thematic sections: education, GP practice organization, workload and role of the GP in society during the COVID-19 pandemic. These themes were identified based on the limited existing literature and concerns raised by representatives of GP trainees and trainers. Each section included three closed-ended questions, mainly answered by a 5-point Likert scale, and one or two open-ended questions. Open-ended questions aimed towards creating a better understanding of the quantitative data and to gain more insight in participants' experiences. The survey was developed by LVP, RR, and GG. To verify face validity and content validity, the questions were reviewed, piloted, and approved by the GP trainers, trainees and medical faculty representatives of the Educational Program Committee (POC). The survey was designed in Qualtrics ${ }^{\circledR}$ and sent to participants in September 2020, using the official communication channels of ICHO in order to reach all Flemish GP trainees $(N=852)$ and GP trainers $(N=1204)$, active in the period March - September 2020. Before completing the online survey, an informed consent was asked from the participants. The survey is available in Additional file 1 (survey for GP trainees) and Additional file 2 (survey for GP trainers).

The data collected by the online survey were analyzed anonymously. Only respondents who answered demographic and at least one closed-ended question were included. Descriptive statistics were used to create an understanding of the quantitative data, by creating frequency Tables. GP trainers were compared to GP trainees using the Chi-squared test. The qualitative dataset was initially analyzed separately by authors LC, GP trainee, and AVR, GP trainer. A thematic analysis was conducted within a realist approach. Semantic themes were identified by using an inductive approach $[25,26]$. Secondly, both authors defined and wrote down together the themes that had been found to understand the data to its fullest [26]. Given that one of the open-ended question was formulated in an ambivalent way, it was impossible to know whether respondents' answers were indicating positive or negative elements. Therefore, it was eliminated from further analysis. Between-method triangulation was performed to create a better understanding of the descriptive statistics and qualitative results and to detect convergent findings [27, 28].

The study design was approved by the Ethical Committee of the Antwerp University Hospital/University of Antwerp, study number 20/51/709.

\section{Results}

The demographics of the participants are represented in Table 1.

Twenty-five percent $(N=216)$ of GP trainees completed the survey, of which $71 \%$ were female. Half of the GP trainees (55\%) were working in a group practice (> 2 graduated GPs), others were active in a duo practice (15\%), solo practice (13\%), community health center (8\%) and hospital setting (9\%).

Twenty-six percent $(N=311)$ of GP trainers participated, of which $51 \%$ were female. GP trainers were active in a group practice $(59 \%)$, duo practice $(19 \%)$ or community health center (6\%). Only $15 \%$ had a solo practice. Half of the GP trainers (48\%) had minor experience as a trainer and had previously trained $1-3$ trainees, $8 \%$ had no prior experience. Whereas $15 \%$ of the GP trainers had supervised more than 10 trainees, $30 \%$ had moderate experiences by guiding $4-10$ trainees in the past. In the following paragraphs, for each section we report the quantitative data, presented in Table 2, followed by a qualitative analysis of the qualitative information.

Table 1 The demographics of the participants both in absolute numbers (N) and in percentages (\%)

\begin{tabular}{|c|c|c|c|c|}
\hline & \multicolumn{2}{|c|}{$\begin{array}{l}\text { GP trainees } \\
(N=216)\end{array}$} & \multicolumn{2}{|c|}{$\begin{array}{l}\text { GP trainers } \\
(N=311)\end{array}$} \\
\hline & $\mathbf{N}$ & $\%$ & $\mathrm{~N}$ & $\%$ \\
\hline \multicolumn{5}{|l|}{ Gender } \\
\hline Female & 154 & 71.3 & 159 & 51.1 \\
\hline Male & 62 & 28.7 & 152 & 48.9 \\
\hline \multicolumn{5}{|l|}{ Type of GP practice } \\
\hline Group practice & 118 & 54.6 & 185 & 59.5 \\
\hline Duo practice & 33 & 15.3 & 60 & 19.3 \\
\hline Solo practice & 28 & 13.0 & 47 & 15.1 \\
\hline Community health center & 18 & 8.3 & 18 & 5.8 \\
\hline Hospital & 19 & 8.8 & 1 & 0.3 \\
\hline \multicolumn{5}{|l|}{ Location of GP practice } \\
\hline Rural & 40 & 18.5 & 78 & 25.1 \\
\hline Suburban & 86 & 39.8 & 121 & 38.9 \\
\hline Urban & 71 & 32.9 & 111 & 35.7 \\
\hline \multicolumn{5}{|c|}{ Amount of previously trained GP trainees } \\
\hline 0 trainees & & & 24 & 7.7 \\
\hline $1-3$ trainees & & & 148 & 47.6 \\
\hline $4-10$ trainees & & & 94 & 30.2 \\
\hline$>10$ trainees & & & 45 & 14.5 \\
\hline
\end{tabular}


Table 2 Representation of the quantitative data

\begin{tabular}{|c|c|c|c|c|c|c|c|c|}
\hline & \multicolumn{2}{|c|}{ GP trainers } & \multicolumn{2}{|c|}{ GP trainees } & \multirow{2}{*}{$\begin{array}{l}\text { Degrees of } \\
\text { freedom }\end{array}$} & \multirow[t]{2}{*}{ Sample size $\mathrm{N}$} & \multirow{2}{*}{$\begin{array}{l}X^{2} \\
\text { statistic } \\
\text { value }\end{array}$} & \multirow[t]{2}{*}{$p$ value } \\
\hline & Mean & $95 \% \mathrm{Cl}$ & Mean & $95 \% \mathrm{Cl}$ & & & & \\
\hline \multicolumn{9}{|l|}{ Education } \\
\hline Opportunity to learn new aspects of GP & 3.85 & $3.74-3.97$ & 3.39 & $3.23-3.55$ & 4 & 527 & 27.5 & $<0.001$ \\
\hline Quality of learning opportunities ${ }^{a}$ & 1.60 & $1.54-1.67$ & 1.29 & $1.22-1.36$ & 2 & 527 & 46.5 & $<0.001$ \\
\hline Appreciation of online lectures & & & 3.05 & $2.89-3.20$ & & & & \\
\hline Quality of online seminars & & & 1.43 & $1.35-1.50$ & & & & \\
\hline Accessibility of GP coach & & & 2.93 & $2.83-3.02$ & & & & \\
\hline \multicolumn{9}{|l|}{ Practice organization } \\
\hline Improving risk management & 3.44 & $3.33-3.56$ & 3.36 & $3.24-3.48$ & 4 & 493 & 11.2 & 0.03 \\
\hline How to perform telehealth consultations & 4.51 & $4.43-4.60$ & 4.24 & $4.12-4.37$ & 4 & 493 & 17.3 & 0.002 \\
\hline Work in out-practice COVID-19 care centers & 3.79 & $3.63-3.95$ & 4.05 & $3.87-4.24$ & 4 & 493 & 5.2 & 0.27 \\
\hline \multicolumn{9}{|l|}{ Workload } \\
\hline Working hours ${ }^{\mathrm{a}}$ & 1.98 & $1.90-2.06$ & 2.26 & $2.15-2.36$ & 2 & 485 & 15.9 & $<0.001$ \\
\hline Stress at work ${ }^{a}$ & 2.07 & $2.01-2.13$ & 2.16 & $2.09-2.24$ & 2 & 485 & 3.8 & 0.15 \\
\hline Intensity of on-call shifts & 3.46 & $3.33-3.59$ & 4.04 & $3.89-4.18$ & 4 & 485 & 33 & $<0.001$ \\
\hline \multicolumn{9}{|l|}{ The role of GP in society } \\
\hline Cooperation with other health care providers & 3.33 & $3.25-3.42$ & 2.87 & $2.77-2.96$ & 4 & 476 & 36.5 & $<0.001$ \\
\hline Support by the government & 2.18 & $2.05-2.31$ & 1.97 & $1.82-2.11$ & 4 & 476 & 9.3 & 0.05 \\
\hline
\end{tabular}

Means and confidence intervals according to a 5-point Likert scale varying from strongly disagree (1) to strongly agree (5)) as well as the comparison of GP trainers to GP trainees. ${ }^{\text {a } 3-p o i n t ~ L i k e r t ~ s c a l e ~}$

\section{Education}

\section{Descriptive statistics}

A vast majority of both GP trainees (63\%) and GP trainers (76\%) believed that COVID-19 had offered new and different learning opportunities. Half of the GP trainers (51\%) indicated that the quality of learning opportunities in clinical practice during the COVID-19 pandemic was equal to the period before the pandemic, whereas only $23 \%$ of the GP trainees agreed. This contrast is visualized in Fig. 1 and Table 2. Up to 74\% of the GP trainees believed that the quality of these learning opportunities had decreased. GP trainees were divided in their appreciation of online lectures as presented in Table 2: $33 \%$ experienced online lectures as effective but another $39 \%$

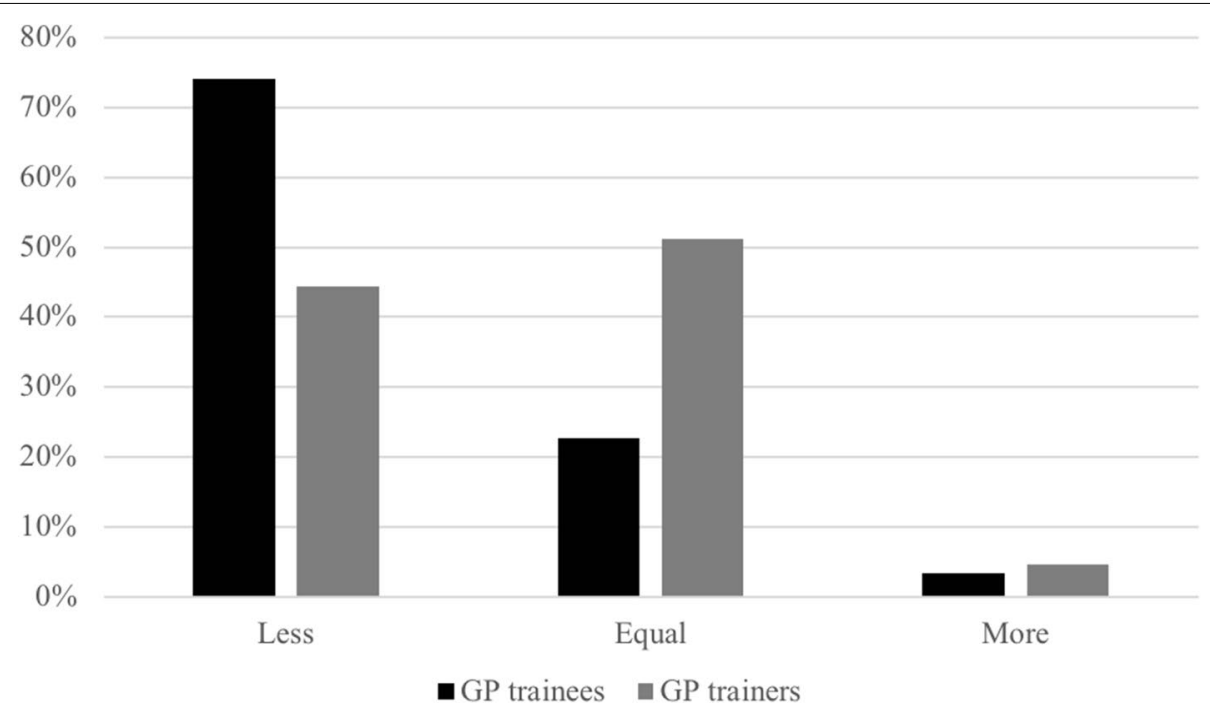

Fig. 1 Quality education moments during the COVID-19 pandemic compared to the period before. Percentage of answers on the question 'if quality education moments were facilitated less, equal or more often during COVID-19 pandemic compared to the period before' 
disagreed and 28\% neither agreed nor disagreed. Almost all of the seminars (94\%) were switched to online sessions. Three out of five GP trainees (59\%) experienced the online seminars to be of lower quality, 39\% reported that the quality was equal. Only $2 \%$ thought the quality of the seminars had increased during the COVID-19 pandemic. However, $74 \%$ of the GP trainees were able to approach their GP coach as easily as before.

\section{Thematic analysis}

According to the open-ended questions presented in Table 3, GP trainees and trainers acquired similar skills during the COVID-19 pandemic. Main topics learned by both groups were executing telehealth consulting, improving knowledge on the COVID-19 virus, pathology and flexibility due to the ever-changing working circumstances and guidelines during the pandemic. Moreover, GP trainees were able to improve their organizational skills whilst GP trainers were more likely to appreciate a well-organized cabinet and collaboration with other health care partners such as GP colleagues, hospitals, and primary care networks. GP trainees have learned to improve communication skills towards patients and colleagues in many aspects. Clear communication with colleagues and patients was perceived as an important factor in the flexibility and organization of the working circumstances. New communication skills were especially obtained by telehealth consulting and providing care in the absence of physical contact.

However, despite several new learning opportunities, GP trainees indicated an even greater loss in learning possibilities related to the regular GP practice and care. The full scope of challenges is shown in Table 4 . Online lectures as well as seminars were found to be of lower quality, due to the obliged online format but also due to the predominance of COVID-19 over other essential learning objectives. Especially peer-to-peer learning was limited due to a lack in face-to-face interactions. GP trainers appreciated their online sessions because no traveling time was needed.

\section{Practice organization Descriptive statistics}

Practice organizations have had to adapt to the health crisis in several ways. COVID-19 has changed the perception of good risk management by $49 \%$ of GP trainees and $56 \%$ of the trainers. For the first time telehealth consults were financially remunerated in Belgium and were introduced as such in the daily life of GP [22]. Most of GP trainers (93\%) and GP trainees (88\%) indicated that they learned how to perform these telehealth consultations. Eight out of ten (79\%) GP trainees indicated to work in out-practice COVID-19 care centers, but only $71 \%$ of GP trainers confirmed that their trainee engaged in such services, see Table 2 .

\section{Thematic analysis}

Table 5 shows that COVID-19 challenged practice organization in many ways.

GP trainers indicated that a good practice organization, including administrative support, strict working hours and appointments, has helped to tackle the COVID-19 pandemic. They perceived the lack of governmental support and the lack of regular GP care as main organizational challenges in addition to finding a right balance

Table 3 The thematic analysis of learning opportunities as experienced by GP trainers and trainees

\begin{tabular}{|c|c|c|c|}
\hline \multicolumn{4}{|l|}{ Education opportunities } \\
\hline & Themes & Specifications & Citations \\
\hline \multirow[t]{4}{*}{ GP trainers and trainees } & Flexibility & $\begin{array}{l}\text { Implementing ever-changing guidelines, crisis manage- } \\
\text { ment }\end{array}$ & \\
\hline & $\begin{array}{l}\text { Practice organisation } \\
\text { and management }\end{array}$ & $\begin{array}{l}\text { Teamwork, appointments, practice organisation, popula- } \\
\text { tion health }\end{array}$ & $\begin{array}{l}\text { GP trainee: "They expected I helped in } \\
\text { practice organization, experience was less } \\
\text { important during the pandemic." }\end{array}$ \\
\hline & Knowledge on COVID-19 & & \\
\hline & Telehealth consults & New communication channels, detecting red flags & \\
\hline \multirow[t]{3}{*}{ GP trainers } & Cooperation & Other GP practices, COVID-19 testing, hospitals & \\
\hline & Online lectures & No traveling time needed & \\
\hline & GP trainees & Better knowledge of new guidelines & $\begin{array}{l}\text { "GP trainees are real doctors, they easily } \\
\text { get used to and implement to new } \\
\text { guidelines and corresponding practice } \\
\text { organisation." }\end{array}$ \\
\hline \multirow[t]{2}{*}{ GP trainees } & Communication skills & Patient education, bad news, anxiety & \\
\hline & Self care & Personal limits, infection prevention & \\
\hline
\end{tabular}


Table 4 The thematic analysis of education challenges as experienced by GP trainers and trainees

\begin{tabular}{|c|c|c|c|}
\hline \multicolumn{4}{|l|}{ Education challenges } \\
\hline & Themes & Specifications & Citations \\
\hline \multirow[t]{3}{*}{ GP trainers and trainees } & Lack of regular GP care & $\begin{array}{l}\text { Lack of chronic care, health prevention, care } \\
\text { postponed, monotonous }\end{array}$ & $\begin{array}{l}\text { GP trainer: "I admit my GP trainee was responsible } \\
\text { for COVID-19 care so I could focus on regular health } \\
\text { care for my patients." }\end{array}$ \\
\hline & Telehealth consults & $\begin{array}{l}\text { Lack of in-person contact with patients, depth, } \\
\text { time consuming }\end{array}$ & \\
\hline & Administrative tasks & $\begin{array}{l}\text { Sick leave notes, ever-changing guidelines, IT } \\
\text { troubles }\end{array}$ & $\begin{array}{l}\text { GP trainee and trainer: "I feel more like a secretary } \\
\text { than a doctor." }\end{array}$ \\
\hline GP trainers & Self care & Difficulties in work-life balance & \\
\hline \multirow[t]{3}{*}{ GP trainees } & Patients & $\begin{array}{l}\text { Impatient, less understanding, patients are } \\
\text { scared of coming to the cabinet }\end{array}$ & \\
\hline & Less intervision & $\begin{array}{l}\text { With GP trainer and other direct colleagues, } \\
\text { lower quality of seminars }\end{array}$ & \\
\hline & Lectures & & $\begin{array}{l}\text { "Lectures seem of less importance than before } \\
\text { COVID-19 and the quality is lower." }\end{array}$ \\
\hline
\end{tabular}

Table 5 GP trainers and trainees perceived a negative impact of COVID-19 in practice organization and in their personal lives

\begin{tabular}{|c|c|c|c|}
\hline \multicolumn{4}{|c|}{ Negative impact of COVID-19 } \\
\hline & Themes & Specifications & Citations \\
\hline \multirow[t]{8}{*}{ GP trainers and trainees } & Telehealth consults & $\begin{array}{l}\text { Intense, new way of consulting, overwhelm- } \\
\text { ing regular consultations }\end{array}$ & "call your GP-phenomene" \\
\hline & Ever-changing guidelines & & $\begin{array}{l}\text { "Guidelines adapting continuously to evolving } \\
\text { pandemic requiring practice re-organisation at } \\
\text { multiple times." }\end{array}$ \\
\hline & Government & & $\begin{array}{l}\text { "GP care was at the center of COVID-19 care, } \\
\text { however we were rarely consulted in the policy- } \\
\text { making. Therefore, the character of our profession } \\
\text { changed profoundly." }\end{array}$ \\
\hline & Administrative tasks & $\begin{array}{l}\text { Sick leave notes, implementing test strategies, } \\
\text { information for patients, contact tracing }\end{array}$ & \\
\hline & Increasing workload & $\begin{array}{l}\text { COVID-19 care, regular health care, catching } \\
\text { up postponed health care }\end{array}$ & \\
\hline & Insecurity and anxiety & $\begin{array}{l}\text { Unknown disease, fear to misdiagnose, lack of } \\
\text { personal protection material, scared of infect- } \\
\text { ing family or friends }\end{array}$ & \\
\hline & Lack of passion for the job & & \\
\hline & New content of GP practice & & $\begin{array}{l}\text { "COVID-19 care creates monotonous work which } \\
\text { changed the character of GP care profoundly." }\end{array}$ \\
\hline
\end{tabular}

between regular and COVID-19 care. GP trainers admitted to being tempted to engage the GP trainee mainly or only for COVID-19 care. Changes to the governmental- and scientific guidelines were insufficiently communicated to the population, as well as a lack of personal protection material were experienced. GP trainees and trainers experienced long phone calls from patients and overwhelming administration work, including writing sick-leave certificates and testing on COVID-19 for nonmedical purposes.
Additionally, both GP trainees and trainers indicated that telehealth consulting was a major challenge. They often felt that physical contact was missing and as a result compromised patient's understanding. A fear of missing important diagnoses besides COVID-19 was reported. GP trainees also experienced more difficulties reaching out to vulnerable patient groups because of the new ways of consulting. All those elements were perceived as a strain on the work- (private) life balance according to GP trainers. 


\section{Workload}

\section{Descriptive statistics}

Working hours were very diverse amongst the respondents. As is shown in Fig. 2 and Tables 2, 42\% of the trainees worked more during the COVID-19 pandemic, 17\% worked less and 40\% indicated that their working hours did not change. However, 29\% of GP trainers reported that their trainee worked less hours. GP trainees experienced more stress at work since COVID-19 (71\%) and the on-call shifts as far more intense (72\%). GP trainers (75\%) also experienced more stress at work but only half of them (52\%) thought on-call shifts were more intense for their trainee.

\section{Thematic analysis}

Overall, respondents regularly indicated that the workload during the first period of higher infection rates (March-May 2020) was acceptable, whereas the workload during the beginning of the second period of increasing infection rates (September 2020) was intolerable and is still increasing. When non-urgent care resumed, a balance between all different tasks had to be found. However, COVID-19 remained an overall priority and especially GP trainees felt that their work was still monotonous and concentrated on the pandemic. The increased workload and work stress were mainly caused by the changing guidelines and health care organization requirements, of which GP played a main role. COVID-19 pushed back the core practice of GPs, posing a major organizational and motivational challenge. The administrative overload and communication with patients were experienced as a main strain. Mainly GP trainees experienced patients as less tolerant and understanding, especially over the phone. GP trainees and trainers reported an important fear for the virus itself, including a lack of knowledge on the COVID-19 pathology. However, the main fear of the respondents was getting infected with COVID-19 themselves or to infect their close contacts. In addition, some respondents indicated to avoid personal contact with their peers, despite their emotional needs.

Motivating factors were very similar for GP trainees and trainers, as can be seen in Table 6. Overall, they experienced most support from their direct colleagues and peers in formal and mostly informal discussions. GP trainers indicated their trainee was of great support in keeping up to date with COVID-19 guidelines. An important sense of solidarity amongst GPs from different practices was established during the pandemic. A good organization of working shifts and efforts of administrative or nursing employees could decrease the workload. Outside the work setting the respondents found distraction and motivation by planning free time and spending time with their friends and family. Many of them continued or increased sport activities and meditation.

\section{The role of GP in society Descriptive statistics}

Since the beginning of the pandemic, GP trainers (48\%) reported an increase in their cooperation with other health care providers compared to only $19 \%$ of GP trainees, see Table 2 . In terms of support by the government, $74 \%$ of GP trainees and 69\% of GP trainers felt insufficiently supported.

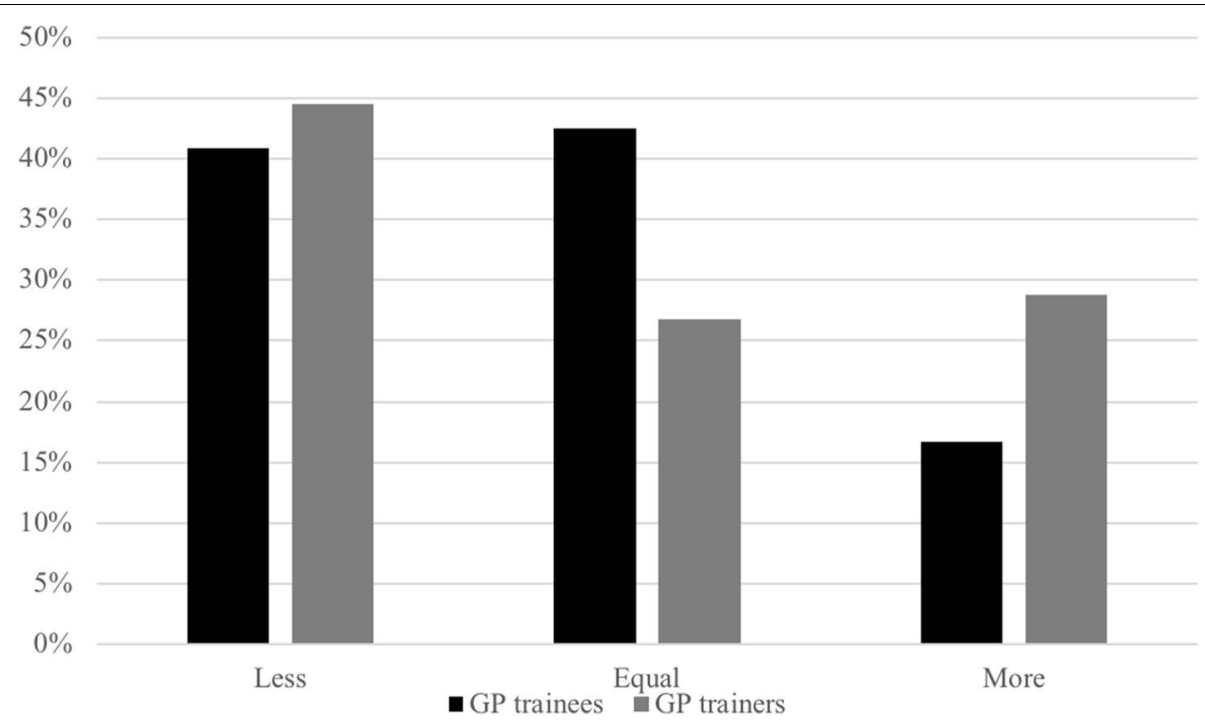

Fig. 2 Working hours during the COVID-19 pandemic compared to the period before. Percentage of answers on the question' if GP trainees worked less, equal or more hours during the COVID-19 pandemic compared to the period before' 
Table 6 The support systems experienced by GP trainers and trainees during the COVID-19 pandemic

\begin{tabular}{|c|c|c|c|}
\hline \multicolumn{4}{|l|}{ Support systems } \\
\hline & Themes & Specifications & Citations \\
\hline \multirow[t]{6}{*}{ GP trainers and trainees } & Colleagues & Venting, solidarity & \\
\hline & Practice organization & Structured work, clear working hours, administrative support & \\
\hline & Personal network & Family, partner, friends & \\
\hline & Perspective & & $\begin{array}{l}\text { "At least we } \\
\text { have a job." } \\
\text { "It is only } \\
\text { temporary." }\end{array}$ \\
\hline & Clear guidelines & COVID-19 guidelines regarding testing, case identification & \\
\hline & Time off & Vacation trips, leisure time activities, sports, meditation & \\
\hline GP trainers & Patient's support & Personal protection material, recognition & \\
\hline
\end{tabular}

\section{Thematic analysis}

By end of September 2020, the respondents noted an increase in the numbers of patients infected with COVID-19 and many patients were less obedient to the government restrictions imposed to limit the spread of COVID-19. Table 7 shows the measures the respondents propose to improve COVID-19 care and GP care in general.

GPs asked for recognition of the role of primary care and GP in tackling the COVID-19 pandemic as well as in general health care. Therefore, GP trainees as well as trainers asked for more involvement in decision making processes concerning their work, finances, and organization. For GP trainees and trainers, the need to simplify administrative issues regarding sick-leave certificates was a major issue of concern.

Respondents had been asking for financial support, in order to make it possible to develop multidisciplinary practices. GP trainers also pleaded for remuneration for telehealth consulting to be permanent. GP trainees and trainers stated that they would like better cooperation amongst primary care networks as well as other health care workers. IT solutions and e-health platforms can play an interesting role in improving cooperation according to several GP trainers, whereas GP trainees more often indicated the need for nurses or paramedics in performing COVID-19 testing, especially for asymptomatic people.

Table 7 The thematic analysis of proposed measures to improve GP care during the COVID-19 pandemic and beyond

\begin{tabular}{|c|c|c|c|}
\hline \multicolumn{4}{|c|}{ Measures to improve GP care during the COVID-19 pandemic and beyond } \\
\hline & Themes & Specifications & Citations \\
\hline \multirow[t]{6}{*}{ GP trainers and trainees } & Administrative simplification & $\begin{array}{l}\text { Uniform sick leave notes, patient education, IT } \\
\text { tools, improving telehealth }\end{array}$ & \\
\hline & Financial support & $\begin{array}{l}\text { Telehealth consults, administrative employees, } \\
\text { nursing employees, remuneration for multidis- } \\
\text { ciplinary practices }\end{array}$ & \\
\hline & Recognition for GP care & $\begin{array}{l}\text { Participations of GP representatives in policy } \\
\text { making, recognition for the central role of GPs } \\
\text { in the health care provision to all }\end{array}$ & \\
\hline & Communication & $\begin{array}{l}\text { Clear guidelines and regulations towards the } \\
\text { population, communication to subgroups }\end{array}$ & \\
\hline & Patient education & & $\begin{array}{l}\text { "Patients should be able to take more responsi- } \\
\text { bilities to improve their health and understand } \\
\text { possible symptoms." }\end{array}$ \\
\hline & Crisisplan & $\begin{array}{l}\text { Better preparation for possible future health } \\
\text { crisises by policy makers }\end{array}$ & \\
\hline \multirow[t]{2}{*}{ GP trainers } & Increasing cooperation & $\begin{array}{l}\text { With policy makers, other health care provid- } \\
\text { ers, paramedics }\end{array}$ & \\
\hline & Health prevention & $\begin{array}{l}\text { Vaccinations, preventive health care, informa- } \\
\text { tion for the population }\end{array}$ & \\
\hline
\end{tabular}


However, improvements are not only required within GP practice; respondents also saw a need to focus on patient education and empowerment. Moreover, they claimed the need for an action plan in preparation for a future health crisis.

Both GP trainers and trainees felt an important change in clinical practice and a decrease in actual health care and prevention care since March 2020. Thence and the COVID-19 pandemic, 24 (11\%) GP trainees and 13 (4\%) GP trainers spontaneously mentioned losing their passion for their profession and one respondent actively considered quitting as a GP.

\section{Discussion}

We aimed to investigate how GP trainees and trainers experienced the changes in education and clinical practice during the COVID-19 pandemic. This study showed that the COVID-19 pandemic created challenges as well as opportunities for GP trainees and trainers in their clinical practice and during the educational activities. Interestingly, challenges were often interlined to the opportunities. Hereafter, we will discuss how these challenges interact with the opportunities.

\section{Education}

Both groups of participants experienced new learning opportunities due to the COVID-19 pandemic. Mostly, organization skills were developed due to the changing guidelines for COVID-19 treatment and testing strategy [12]. In addition, the introduction and implementation of telehealth consulting required new communication skills [29-31]. GP trainees and GP trainers had to learn and recognize red flags, to diagnose and to explain treatments without any physical examination. GP trainers were challenged by learning new skills and teaching and supervising these competences in the very same moment $[8,17,18]$. The implementation of the COVID-19 guidelines and the organization of separate consultations for infectious diseases required flexibility and also the need to quickly adapting. GP trainees were actively engaged in the implementation of the guidelines and therefore acquired new organizational skills [17].

GP trainees noticed that online lectures and seminars were missing impact in comparison to in-person sessions $[18,19,32]$. Moreover, seminars were experienced as an important moment to vent and exchange about the impact of COVID-19. GP trainees felt that virtual sessions did not allow venting and exchanging experiences as much as the former in-person sessions did. Currently, lectures and seminars have been integrally transferred into online formats. However, recent literature showed that an in-person session cannot simply be switched to an online session $[7,8,33]$. Several alternative online learning tools should be integrated, especially in the case of peer-to-peer sessions [7, 9, 10, 33, 34]. Our study confirmed that online learning can provide opportunities thanks to the 'anywhere/anytime' principle, but we noticed the advantages and continued appreciation of students towards in-person peer-to-peer learning. Blended learning would be preferable [7, 9, 10, 33, 34].

\section{Practice organization}

GP trainees experienced that COVID-19 was overrepresented in their clinical work. Moreover, GP trainers admitted they were tempted to direct COVID-19 cases more often to their trainee. Based on the qualitative data, we assume that GP trainers maintain the professional relationships with their patients, by continuing to focus on chronic healthcare. Moreover, GP trainers assume their trainee is more familiar with the COVID-19 guidelines. As such, the GP trainees lacked learning opportunities in common GP clinical work. Studies amongst different medical specialties confirmed that residents are lacking general clinical practice during the COVID-19 pandemic, as regular care have been postponed [5, 9-11, $32,35]$. Residents were very willing to assist in (primary) medical care during the pandemic but feared an inferior education for their future medical profession $[6-8,10]$.

\section{Workload}

GP trainees and trainers were overwhelmed by the amount of administrative work and experienced more stress since the COVID-19 pandemic. Telehealth consulting reduced actual clinical consults but have not been able to replace them $[30,36]$. Throughout telehealth consulting, GP trainees as well as their trainers feared missing important diagnoses $[29,36]$. Moreover, GP trainees indicated that a lack of common history with the patients increased their insecurity. Other studies confirmed that telehealth consults increased insecurity amongst residents [8-10, 29, 30, 36, 37]. Eventually, the selection of cases suitable for telehealth consulting should be reviewed and more targeted to follow-up consults instead of acute symptomatology such as respiratory infections [10, 29, 30, 36-38].

Seventy-two percent of GP trainees experienced oncall shifts as more intense since the COVID-19 pandemic, but this was recognized by only $52 \%$ of GP trainers. Literature confirmed that on-call shifts were experienced to be more intense [9-11]. No clarification for this major difference in perception between GP trainees and their trainers could be found. We presumed that the lack of formal supervision could diminish the ability to discuss out-of-practice activities [10, 31]. However, tele supervision does not imply any safety risks for patient's health care and therefore should not increase 
insecurity amongst GP trainees [10, 17, 20, 31]. During on call shifts, patients are less familiar to the GP trainee, and this might increase the distress for misdiagnosis [30]. Furthermore, the organization of on call shifts changed regularly because of the evolving COVID-19 pandemic and changing guidelines. Whereas GP trainers can rely on their experience in these unpredictable circumstances, GP trainees cannot [30, 36].

\section{The role of GP in society}

GP trainers and trainees felt that COVID-19 was taking over regular GP work and has impacted their overall work satisfaction. Although we did not survey job appreciation systematically amongst our respondents, one out of $10 \mathrm{GP}$ trainees and one out of $25 \mathrm{GP}$ trainers spontaneously mentioned that they have lost their job satisfaction. Other studies outlined increasing mental health issues during clerkships and amongst trainees, but to our knowledge no other study has previously examined this with GP trainees [8-11, 34]. Considering these results, we feared GP trainers and trainees might eventually quit their medical career.

Measures such as reducing sick-leave notes or other medical certificates and financial aid for administrative and (para-)medical support, need to be put in place in short and long term to improve the work life and work content of Belgian GPs. Moreover, there is a need to increase financial and moral recognition for the role GPs have in the health care system, in society and in their patients' lives to safeguard the core of GP practice $[9,11$, 35].

\section{Strengths and limitations}

By including both GP trainers and trainees, the perspective of all main actors in GP education was investigated in this study. Only one other study was found with a similar set-up, [10] in most other studies, only the trainees were interviewed $[8,10]$. As GP education in many countries includes workplace learning, the role of the GP trainer is of major importance $[5,10,20]$. By including their perspective and comparing to GP trainees, the challenges and possibilities for the organization of education during a pandemic could be fully described.

The overall response rate of $26 \%$ is a reasonable response rate for online surveys and sufficient for a confidence level of at least $80 \%[39,40]$. Although we used the official communication channels for GP trainers and GP trainees, the lower response rate may be due to an increasing workload because of the rising COVID19 infections and the insufficient use of boosting methods to encourage GP trainers and trainees to participate [40, 41]. Moreover, the response rate for online surveys is known to be $10 \%$ lower than for other survey methods despite the use of encouraging methods such as reminders or incentives [40,42]. However, both groups of respondents, GP trainers and trainees, were representative for gender and region of practice compared to all GP trainers and trainees in Flanders. Whereas other studies focused on a specific university or local region only, this survey was sent out to all GP trainers and their trainees in Flanders [10, 34].

As the COVID-19 pandemic developed rapidly, a swift response to the impact on GP trainees and trainers was essential for the educational organization. Therefore, only content and face validity were assessed in the study design. It can be seen as a limitation that reliability or construct validity were not measured. However, this study combined descriptive statistics and qualitative thematic analysis of responses to open-ended questions to better understand the impact on GP education during the COVID-19 pandemic. The thematic analysis created the opportunity to further clarify and find in-depth information on the quantitative findings.

\section{Future research}

The COVID-19 pandemic stresses the processes and outcomes of GP education. Therefore, a profound investigation of threats for job satisfaction and the support systems of our trainees and trainers should be on the agenda in order to cope with future pandemic threats and to facilitate the GP core clinical activities. Online learning could be further developed and evaluated and fully integrated in blended workplace learning. Telehealth consults should be actively included in the education program for GP trainers and trainees.

\section{Conclusion}

COVID-19 has had a major impact on the education and day-to-day work of GP trainees and GP trainers. With online learning being introduced, GP trainers and trainees reported advantages and disadvantages to Online learning, as such blended learning would be preferable.

New skills were acquired during the COVID-19 pandemic such as telehealth consults, communication and organizational skills. However, GP trainees and trainers experienced multiple challenges because of COVID19: an administrative overload, a mandatory focus on COVID-19 care and increased insecurity in diagnoses as well as personal protection. GP trainees especially lacked peer-to-peer contact. GP trainers' and trainees' job satisfaction decreased because of the current working circumstances and work content.

Good practice organization, collaboration and communication with colleagues were essential to face the challenges posed by COVID-19. Other proposed measures to 
regain the core of GP care were administrative simplification and financial support for administrative and (para) medical support in GP cabinets.

Further qualitative and quantitative research may help to further identify and understand the challenges and support systems for GP and GP workplace-based learning in times of stress on the health system like the COVID19 pandemic. Additionally, the measures to improve the position of GP in the health system should be placed on decision makers' agenda.

\section{Abbreviations}

GP: General Practice; ICHO: Interuniversity Centre for the Education of General Practitioners; POC: Educational Program Committee.

\section{Supplementary Information}

The online version contains supplementary material available at https://doi. org/10.1186/s12909-022-03174-4.

Additional file 1. Study survey for GP trainees.

Additional file 2. Survey for GP trainers.

\section{Acknowledgements}

Not applicable.

\section{Authors' contributions}

GG and RR are respectively general director and president of the educational steering group of the Interuniversity Centre for the Education of General Practitioners (ICHO) and initiated this study. The conception and study design were set up by NM, RR, GG and LVP. LVP developed the survey. The POC of $\mathrm{ICHO}$ revised the survey. All authors are member of the POC and as such revised the survey. Descriptive statistics were performed by LVP. Thematic analysis was performed by LC and AVR. LC drafted the first manuscript. Critical revision of the manuscript was done mainly by $N M$ and $B S$ as well as by $R R$, LVP and AVR. All authors read and approved the final manuscript.

\section{Authors' information}

Lotta Coenen MD.

Dr. Lotta Coenen obtained a master's in medicine in 2018 and initiated a training in gynaecology-obstetrics. In 2019, she started as a GP trainee in a duo practice in a small Flemish town. She is board member of 't HOP, an organisation that defends the interests of all Flemish GP trainees and as such member of the Permanent Education Committee (POC) of the Interuniversity Centre for the Education of General Practitioners (ICHO). As a former European youth representative of the national youth council, she is mainly interested in health care for vulnerable groups and the well-being and quality education of GP trainees

Louise Vanden Poel PsyM.

Louise Vanden Poel is trained as a psychotherapist. Currently she works as programmes coordinator for General Practice education at KU Leuven at the department of Public Health and Primary Care.

Birgitte Schoenmakers MD, PhD.

Prof. Dr. Birgitte Schoenmakers is General Practitioner and head of the University GP group practice. She is professor at the Department of Public Health and Primary Care of KU Leuven where she is responsible for the interuniversity master program for GP education. Besides, she is in charge of postgraduate education. Her research topics of interest are the care for the elderly, practice organization, health care diversity and patient participation in medical education.

Arne Van Renterghem MD.

Dr. Arne Van Renterghem is GP trainer in a group practice in Merelbeke, Flanders. He is the regional deputy at the Orde der Artsen, the Belgian association for doctors. Moreover, he is president of OVERSTAG, an organization that represents Flemish GP trainers. As such, he is member of the Education Committee of $\mathrm{ICHO}$ and board member of Sui vzW.

Guy Gielis PsyM.

Guy Gielis is active as psychotherapist. He is the director of ICHO and board member of Sui vzw.

Roy Remmen MD, PhD.

Prof. Dr. Roy Remmen works as GP, since more than 30 years. Moreover, he is professor at the University of Antwerp and the University of Hasselt, focusing on out-of-hours primary health care, continuity of care for the elderly and GP education. Prof. dr. Remmen is chair of the Education Committee for GP education of the University of Antwerp as well as of the Education Committee of ICHO.

Nele R. Michels MD, PhD.

Prof. dr. Nele R. Michels works as GP in a group practice. At the Faculty of Medicine of the University of Antwerp, she is vice-president of the Education Committee for GP education and in charge of competence training. At ICHO, she is chair of the commission on workplace learning and as such member of the Education Committee. Furthermore, she is president of EURACT. Her topics of interest are medical education, workplace learning, experience-based learning and capacity building in GP.

\section{Funding}

This study did not benefit from any funding nor any sponsors were involved.

\section{Availability of data and materials}

The datasets used and/or analysed during the current study are available from the corresponding author on reasonable request.

\section{Declarations}

\section{Ethics approval and consent to participate}

The study was approved by the Ethical Committee of the Antwerp University Hospital/University of Antwerp, study number 20/51/709. All aspects of this study were in accordance to the ethical standards of the institutional and/or national research committee and with the 1964 Helsinki declaration and its later amendments.

A formal, written informed consent was obtained from all participants before participation.

\section{Consent for publication}

Not applicable.

\section{Competing interests}

The authors declare that they have no competing interests.

\section{Author details}

${ }^{1}$ Department of Family Medicine and chronic care, Vrije Universiteit Brussels, Laarbeeklaan 103, 1090 Brussels, Belgium. ${ }^{2}$ Faculty of Medicine, KU Leuven, ON II Herestraat 49 - box 400, 3000 Leuven, Belgium. ${ }^{3}$ Department of Public Health and Primary care, KU Leuven, Kapucijnenvoer 7 blok $\mathrm{h}$ - box 7001, 3000 Leuven, Belgium. ${ }^{4}$ Department of Public Health and Primary care, Ghent University, Ghent, Belgium. ${ }^{5}$ Interuniversity Centre for the Education of General Practitioners, Kapucijnenvoer 33 - Blok H - bus 7001, 3000 Leuven, Belgium. ${ }^{6}$ Centre for General Practice, Department of Family Medicine and Population health, Faculty of Medicine and Health Sciences, University of Antwerp, Antwerp, Belgium.

Received: 21 May 2021 Accepted: 8 February 2022

Published online: 19 February 2022

\section{References}

1. World Health Organization. WHO Coronavirus (COVID-19) Dashboard. 2020. https://covid19.who.int. Accessed 20 Sep 2021.

2. Belgian Federal Government Coronavirus: reinforced measures 2020. https://www.belgium.be/en/news/2020/coronavirus reinforced_measu res. Accessed 27 Dec 2020. 
3. United Nations Educational Scientific and Cultural Organization. Education: From disruption to recovery. 2019. https://en.unesco.org/covid19/ educationresponse. Accessed 27 Dec 2020.

4. World Health Organization. Checklist to support schools re-opening and preparation for COVID-19 resurgences or similar public health crises. Geneva:WHO; 2020. p. 20.

5. Ahmed H, Allaf M, Elghazaly H. COVID-19 and medical education. Lancet Infect Dis. 2020;20(7):777-8.

6. Kim SM, Park SG, Koo Jee Y, Song IH. Perception and attitudes of medical students on clinical clerkship in the era of the Coronavirus Disease 2019 pandemic. Med Educ Online. 2020;25(1):1809929.

7. Rose S. Medical Student Education in the Time of COVID-19. JAMA. 2020:323(21):2131-2.

8. Dedeilia A, Sotiropoulos MG, Hanrahan JG, Janga D, Dedeilias P, Sideris M. Medical and Surgical Education Challenges and Innovations in the COVID-19 Era: A Systematic Review. In Vivo. 2020;34(3 suppl):1603-11.

9. Abbas M, Dhane M, Beniey M, et al. Repercussions of the COVID-19 pandemic on the well-being and training of medical clerks: a pan-Canadian survey. BMC Med Educ. 2020;20(1):385

10. Scallan S, Lyon-Maris J. The educational impact of COVID-19: views from UK GP educators and trainees. Educ Prim Care. 2020;31(5):328-9.

11. Khusid JA, Weinstein CS, Becerra AZ, et al. Well-being and education of urology residents during the COVID-19 pandemic: Results of an American National Survey. Int J Clin Pract. 2020;74(9):e13559.

12. Ramsay R, Nashat NH, Thuraisingham C, et al. Reimagining medical education for primary care in the time of COVID-19: a world view. Educ Prim Care. 2021;32(1):2-5.

13. Alvarez-Risco A, Estrada-Merino A, Anderson-Seminario MdIM, et al. Multitasking behavior in online classrooms and academic performance: case of university students in Ecuador during COVID-19 outbreak. Interactive Technology and Smart Education. 2021:18(3):422-34

14. Chirico F, Nucera N. Tribute to healthcare operators threatened by COVID19 pandemic. J Health Soc Sci. 2020;5(2):165-8.

15. Yanez JA, Jahanshahi AA, Alvarez-Risco A, Li J, Zhang SX. Anxiety, Distress, and Turnover Intention of Healthcare Workers in Peru by Their Distance to the Epicenter during the COVID-19 Crisis. Am J Trop Med Hyg. 2020;103(4):1614-20.

16. Zhanga SX, Sun S, Jahanshahic AA. Developing and testing a measure of COVID-19 organizational support of healthcare workers - results from Peru, Ecuador, and Bolivia. Psychiatry Res. 2020;291:113174.

17. Manson DK, Shen S, Lavelle MP, Lumish HS, Chong DH, De Miguel MH, et al. Reorganizing a medicine residency program in response to the COVID-19 pandemic in New York. Acad Med. 2020;95(11):1670-3.

18. Gaur U, Majumder MAA, Sa B, Sarkar S, Williams A, Singh K. Challenges and opportunities of preclinical medical education: COVID-19 crisis and beyond. SN Compr Clin Med. 2020;2(11):1992-7.

19. Roskvist R, Eggleton K, Goodyear-Smith F. Provision of e-learning programmes to replace undergraduate medical students' clinical general practice attachments during COVID-19 stand-down. Educ Prim Care. 2020;31(4):247-54.

20. Solomon G, Allie A, Fakier R, Tadmor D, Ashtiker K, Le Roux C. Family medicine internship support during the COVID-19 pandemic in Cape Town, South Africa - A narrative report. Afr J Prim Health Care Fam Med. 2020;12(1):e1-3.

21. Domus Medica (BE); CMG (BE); Vlaams Patiëntenplatform (BE). Synthese document: Veilige heropstart van reguliere zorg voor patiënten NIET verdacht van COVID-19. 2020. https://overlegorganen.gezondheid.belgie. be/sites/default/files/documents/synthesedocument_veilige_herop start_van_reguliere_zorg_27-04-2020.pdf. Accessed 27 Dec 2020.

22. Rijksinstituut voor ziekte- en invaliditeitsverzekering. Continuïteit en veiligheid van de zorg: advies op afstand door artsen en wachtposten tijdens de COVID-19 pandemie. 2020. https://www.inami.fgov.be/nl/ COVID19/Paginas/continuiteit-veiligheid-zorg-advies-afstand-artsenCOVID19.aspx. Accessed 27 Dec 2020

23. Sciensano. Belgium COVID-19 Epidemiological Situation. 2021. https:// datastudio.google.com/embed/u/0/reporting/c14a5cfc-cab7-4812-848c0369173148ab/page/tpRKB. Accessed 26 Sep 2021.

24. Statbel. Structuur van de Bevolking. 2021. https://statbel.fgov.be/nl/ themas/bevolking/structuur-van-de-bevolking\#figures. Accessed $26 \mathrm{Sep}$ 2021.
25. Braun V, Clarke V. Using thematic analysis in psychology. Qual Methodol Psychol. 2008;3(2):77-101.

26. Maguire M, Delahunt. Doing a thematic analysis: A practical, step-by-step guide for learning and teaching scholars. AISHE-J. 2017;9(3):3351.

27. Fusch P, Fusch GE, Ness LR. Denzin's paradigm shift: revisiting triangulation in qualitative research. J Soc Change. 2018;10(1):19-32.

28. Jick TD. Mixing qualitative and quantitative methods: triangulation in action. Adm Sci Q. 1979;24(4):602-61.

29. Downes MJ, Mervin MC, Byrnes JM, Scuffham PA. Telephone consultations for general practice: a systematic review. Syst Rev. 2017;6(1):128.

30. Greenhalgh T, Wherton J, Shaw S, Morrison C. Video consultations for covid-19. BMJ. 2020;12(368):m998.

31. Miller L. Remote supervision in primary care during the COVID-19 pandemic - the "new normal"? Educ Prim Care. 2020;31(6):332-6.

32. Theoret $C$, Ming $X$. Our education, our concerns: the impact on medical student education of COVID-19; 2020

33. Tabatabai S. Simulations and Virtual Learning Supporting Clinical Education During the COVID 19 Pandemic. Adv Med Educ Pract. 2020:11:513-6.

34. Chandratre S. Medical Students and COVID-19: Challenges and Supportive Strategies. J Med Educ Cuuric Dev. 2020;7:2382120520935059.

35. Danhieux K, Buffel V, Pairon A, et al. The impact of COVID-19 care according to providers: a qualitative study among primary care practices in Belgium. BMC Fam Pract. 2020;21(1):255.

36. Al Hasani S, Al Ghafri T, Al Lawati H, et al. The Use of Telephone Consultation in Primary Health Care During COVID-19 Pandemic, Oman: Perceptions from Physicians. J Prim Care Community Health. 2020:11:2150132720976480.

37. Marshall M, Howe A, Howsam G, Mulholland M, Leach J. COVID-19: a danger and an opportunity for the future of general practice. $\mathrm{Br} J \mathrm{Gen}$ Pract. 2020;70(695):270-1.

38. Alvarez-Risco A, Del-Aguila-Arcentales S, Yanez A, J. Telemedicine in Peru as a Result of the COVID-19 Pandemic: Perspective from a Country with Limited Internet Access. Am J Trop Med Hyg. 2021;105(1):6-11.

39. Nulty DD. The adequacy of response rates to online and paper surveys: what can be done? Assess Eval High Educ. 2008;33(3):301-14.

40. Philips AW, Friendman BT, Utrankar A, Ta AQ, Reddy ST, Durning SJ. Surveys of health professions trainees: prevalence, response rates, and predictive factors to guide researchers. Acad Med. 2017;92:222-8.

41. Van Mol C. Improving web survey efficiency: the impact of an extra reminder and reminder content on web survey response. Int I Soc Res Methodol. 2016;20(4):317-27.

42. Philips AW, Reddy S, Durning SJ. Improving response rates and evaluating nonresponse bias in surveys: AMEE guide No. 102. Med Teach. 2016:38:217-28.

\section{Publisher's Note}

Springer Nature remains neutral with regard to jurisdictional claims in published maps and institutional affiliations.

Ready to submit your research? Choose BMC and benefit from:

- fast, convenient online submission

- thorough peer review by experienced researchers in your field

- rapid publication on acceptance

- support for research data, including large and complex data types

- gold Open Access which fosters wider collaboration and increased citations

- maximum visibility for your research: over 100M website views per year

At BMC, research is always in progress.

Learn more biomedcentral.com/submissions 